
セツキシマブ併用化学療法後に気胸を生じた咽頭癌多発肺転移の 2 症例

○根本俊光、木村健太郎、黒崎元良、大塚雄一郎

成田赤十字病院 耳鼻咽喉科

セツキシマブは本邦において頭頸部癌に対し使用が認められている唯一の分子標的薬であり、優れた有効性が報告されて いる。当科においても2013年 4 月から使用を開始し、特に切除不能な進行、再発症例の予後が改善されている感触がある。 一方、セッキシマブには infusion reaction や皮膚症状など特有の有害事象があり、その管理には注意が必要である。今回咽 頭癌多発肺転移に対し、セツキシマブ併用の化学療法を施行した直後に片側の気胸を呈した 2 症例を経験した。気胸の原因 は完全には解明されていないが、文献的には肺転移巣の急激な縮小により気管支胸膜瘦が生じたとするものが散見される。 当科の症例も 1 例は外科手術の適応となり、転移巣部位の胸膜欠損と気瘦が確認された。癌腫によっては両側気胸の報告も あり、今後全国的に症例数が増加していく中で認識しておくべき合併症と考え、症例を報告し考察を加える。

121

当院においてセツキシマブ投与後にアナフィラキシーショックを発症した 4 例

○竹内 薰、伊藤和行、武田真紀子、小田直治

松江赤十字病院 耳鼻咽喉・頭頸部外科

2012年12月より頭頸部癌にセツキシマブの適応が拡大され、日本でも使用頻度が高くなった。当院で2013年 2 月〜 7 月の 期間にセッキシマブ初回投与を行った症例は 13 例である。2 例目にてセッキシマブ投与開始後にアナフィラキシーショック を発症したため、以後当院ではセツキシマブ投与に際し、ベッドサイドに薬剤セットを用意し、緊急対応を行いやすいよう ラインの接続を工夫し、初回投与時は医師、看護師が投与開始後から 20 分間ベッドサイドで患者の観察を行っている。セツ キシマブ投与を施行した13例のうち 4 例が、初回投与開始20分以内にアナフィラキシーショックを発症した。初発症状は咽 頭違和感、顔面紅潮、空咳、SpO2 低下 $(\leqq 90 \%)$ であり、いずれの症例も、上記症状を呈して数分以内に意識レベル低下、 収縮期血圧 $60 \mathrm{mmHg}$ 以下のショック状態（Grade 4 の副作用）となった。直ちに投与を中止し、アナフィラキシーショッ クに対する緊急対応にて全例症状は軽快した。

\title{
122 当科における80歳以上の高齢者頭頸部癌症例の検討
}

○宮村朋孝、石永 一、中村 哲、千代延和貴、竹内万彦

三重大学大学院 医学系研究科 耳鼻咽喉・頭頸部外科

高齢者に対する癌治療の機会は増加しており、頭頸部領域においても同様の傾向がみられる。高齢者頭頸部癌症例におい ては治療に準ずる合併症が根治治療の妨げになることが多く、また、併存疾患の有無や社会的、精神的、社会的背景が治療 方針を決定するにあたって問題になることが多い。今回われわれは、2008年から 2013 年に当科を受診された 80 歳以上の頭頸

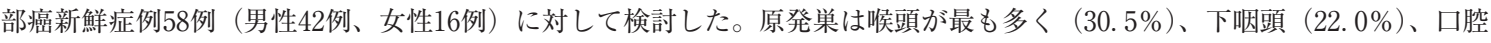
(11.9\%)、中咽頭（10.2\%）であった。根治治療を行った例が44.1\%であり半数以上が姑息的治療、緩和治療となった。総 じて、合併症や PS、価值観、家庭環境などが複雑にかかわり合い、治療内容や経過に影響を及ぼしていた。いずれの治療 法を選択しても治療関連の体力低下や生命予後の短縮を来す可能性があるため、個々の全身状態を十分に評価して治療法を 選択すべきと考える。

\section{3 当科における高齢者頭頸部癌診療の臨床的検討}

$\bigcirc$ 松本宗一、小林泰輔、兵頭政光

高知大学 医学部 耳鼻咽喉科

本格的な高齢化社会をむかえ、耳鼻咽喉科領域においても高齢者の頭頸部癌診療に携わる機会が増加している。高齢者の 癌治療においては、単に年齢のみで根治的治療を控える理由にはならず、一方で、全身合併症を有する症例が高頻度に見ら れるため画一的な治療方針は立てにくい。今回、当科に拈ける高齢者癌診療の現状を明らかにするために、過去 5 年間に当 科外来を受診した頭頸部癌患者について臨床的検討を行った。全頭頸部癌患者は298例、男性241例、女性57例、年齢は19〜 92歳で平均66.3歳であった。このうち75歳以上の高齢者は89例で全体の $29.8 \%$ を占めていた。原発巣は喉頭癌が 33 例と最も 多く、つづいて下咽頭癌が21例であった。これらの患者における治療方針の決定に影響した因子と問題点について報告す る。 


\section{4 後期・超高齢者の頭頸部悪性腫瘍患者の手術治療についての検討}

○北野睦三、寺尾恭一、森川大樹、小林孝光、速水康介、佐藤満雄、山本暁秀、宮下美恵、藤原良平、 齋藤和也、瀬尾＼cjkstart徹、土井勝美

近畿大学 医学部 耳鼻咽喉科

高齢化社会の日本において、高齢者が悪性腫瘍に罹患した際に本人・家族はもちろん医療者も「それは寿命ではないか」 と考えてしまう可能性がある。厚生労働省の平成 24 年簡易生命表によると、男性の平均寿命は 79.94 年、女性の平均寿命は 86. 41年であり、平均余命は75歳で男性11. 57年、女性15.27年、85歳では男性6.00年、女性8. 10年であった。つまり、高齢 という理由だけで無治療や姑息的治療を行うことは難しい。今回、近畿大学附属病院耳鼻咽喉科で2010年 7 月から 2012 年 12 月までに手術治療を行った頭頸部悪性腫瘍患者で75歳以上の後期・超高齢者患者の手術治療について検討を行った。患者数 は52名で、男性38名女性14名であった。平均80.5歳で最高齢は89歳であった。原発部位別患者数は口腔22名、中咽頭 4 名、 下咽頭 5 名、喉頭 9 名、鼻副鼻腔 2 名、耳下腺 2 名、甲状腺 6 名、原発不明 2 名であった。これらの症例から高齢者の手術 治療の問題点などについて文献的考察を加え検討する。

\section{5 高齢頭頸部癌患者に対する診療についてのアンケート結果報告一頭頸部がん専門医の意識一}

○横島一彦、中溝宗永

日本医科大学 医学部 耳鼻咽㑨科

社会の高齢化が今後さらに進むと考えられていることから、高齢頭頸部癌患者診療の一定の指針を明確にする必要がある と思われる。現在、“暦年齢のみでは判断しない”とされているが、何を判断基準にすべきかのコンセンサスが得られてい ないため、診療に当たる医師の意見を問うアンケート調査を行った。225名の頭頸部がん専門医（2013年 7 月時点）宛にア ンケートを郵送し、現在までに得られた 119 通の有効回答を検討の対象にした。回答者の平均年齢は46.2歳であった。高齢 者診療の増加はほぼすべての専門医が感じており、75歳（53\%）または80歳以上（35\%）の患者には特別な配慮が必要。治 療の可否や方法の選択には併存疾患や本人の意欲・病識、家族の協力を最も重要と考えていた。暦年齢による治療の制限に は反対意見は多いものの、医療経済への配慮が必要であるとの意見も少なからず認められた。最後に、無償のアンケートに ご協力いただいた頭頸部がん専門医の皆様に深く感謝・御礼申しあげたい。

\section{6 高齢乳頭癌症例の検討}

○嘉田真平、片岡通子、过村隆司、本多啓吾、神田智子、安里 亮、辻＼cjkstart純 国立病院機構 京都医療センター 耳鼻咽喉科・頭頸部外科

くはじめに>甲状腺乳頭癌は一般的には予後は良好ではあるが、45歳を境に病期が変わる癌であり、高年齢者ほど予後が 悪い傾向がある。今回、高齢甲状腺乳頭癌症例について検討したので報告する。

<対象 $>2005$ 年 4 月〜 2011年 3 月の 6 年間に当院で初回手術加療を施行され、術後 2 年以上経過観察できた 75 歳以上の甲 状腺乳頭癌患者 14 例。同じ病期分類となる 45 歳以上の症例を年齢層で 3 群（75歳以上、60～74歳、 $45 \sim 59$ 歳）にわけて比較 検討し、高齢者の乳頭癌患者の特徵を検討した。

<結果 $>75$ 歳以上（14例）、60～74歳（49例）、45～59歳（41例）の順に記載

T因子: pT1/pT2/pT3/pT4 がそれぞれ 3/4/1/6 例、15/8/14/11例、18/3/16/4例

N因子：pN0/pN1a/pN1b がそれぞれ $5 / 5 / 4$ 例、18/11/20例、17/13/11例

腫瘍径 $($ mean $\pm \mathrm{SD}): 22.6 \pm 14.3 \mathrm{~mm} 、 24.8 \pm 16.5 \mathrm{~mm} 、 15.2 \pm 9.4 \mathrm{~mm}$

担癌患者：なし、 2 例、 1 例 原病死：なし、1 例、なし 他病死： 3 例、 1 例、なし

く考察 $>75$ 歳以上の群に、甲状腺癌による死亡症例は無く、他病死を 3 例認めた。今回のデー夕を踏まえて高齢甲状腺癌 に対する対応を検討する。

\section{AsR スコアを用いた喉頭癌・下咽頭癌に対する喉頭温存手術後の定量的嚥下機能評価}

○鈴木基之、吉野邦俊、藤井 隆、喜井正士、須川敏光、北村公二

大阪府立成人病センター 耳鼻咽喉科

頭頸部癌術後の嚥下機能評価として多く用いられる嚥下造影検査（以下 VF）は定量的評価として日常臨床で用いるのは 困難であった。われわれはこれまでVF の簡便な定量的評価法として AsR スコア ${ }^{1)}$ を用いてきた。外切開による喉頭温存手 術を行った喉頭癌・下咽頭癌41例を対象として、AsR スコアが「直接訓練開始」や「退院時全量経口摂取」の指標となるか 検討を行った。

直接訓練開始直前 VF 時のスコアとその後の直接訓練開始および中断の有無、入院最終回 VF 時のスコアと退院時の栄養 摂取形態の相関を検討した。また、ROC 曲線を用いて各スコアの至適カットオフ値と精度を算出した。

直接訓練継続可能と判定するAsR スコアの至適カットオフ值は 4 で正診率 $95.1 \%$ 、退院時全量経口摄取可能と判定する AsR スコアの至適カットオフ值は 6 で正診率 $85.4 \%$ であった。

AsR スコアが「直接訓練開始」や「退院時全量経口摂取」という臨床的に重要な判断をする際の定量的な指標として有用 であることが示唆された。

1）藤本保志、他：嚥下医学 1 (1)：153-158， 2012 